\title{
EMERGENCE ACTIVITY OF POWDER POST BEETLE, LYCTUS BRUNNEUS (STEPHENS), FROM INFESTED WOODEN BOARDS STORED FOR DEFINITE PERIOD
}

\author{
M. A Batt and H. M. Ahmed \\ Plant Protection Research Institute, Agricultural Research Centre, Dokki, Giza, Egypt. \\ Received: Jan. 30,2018 \\ Accepted: Feb. 14, 2018
}

\begin{abstract}
The results of the current work showed that Lyctus brunneus Steph. beetles (Coleoptera : Bostrichidae) emerge from storage wood in closed places during different occurrence periods and consider as renewal source for infestation.

Three occurrence periods were observed during storage period of about 24months. The 1 st occurrence periods recoded 6 months of beetles emergence and appeared the highest percentage of emerged beetles (74.8\%), followed by the 2nd occurrence which its duration 4 months and detected 17.48\% emergence then 3rd occurrence which recorded the least percentage of emergence (7.72\% emergence) through four successive months.

The effect of temperature showed positive significant correlation with number of emerged beetles during $1 \underline{\text { st }}$ occurrence period, and the correlation was positive and highly significant during 3 rd occurrence period. Whereas, the both of relative humidity and moisture content of wood gave highly negative significant correlation during the 1 st and the 3rd occurrence periods, while the correlation was highly positive significant during the 2 nd occurrence period for both relative humidity and wood of moister content.
\end{abstract}

Key words: Powder-post beetle, Coleoptera: Bostrichidae, Lyctus brunneus, stored wood

\section{INTRODUCTION}

Lyctus brunneus Steph. beetle is considered one of most of serious powder post beetles attacking either raw or working wood. Infestation may occur anywhere in the structure where susceptible timber has been used (for example, in sub-floor, areas living space, roof space or in furniture and artefacts).

Lyctid powder post beetles cause severe damage to seasonal hardwood, wooden floors and furniture. The damage is usually not evident until the emergence holes of adults were observed. Reinfestation of timber is common and may continue until the food resource is completely used up. To the point, Thakur (1999) found that Lyctus africanus Lesne caused significant timber losses by their larval activities.
Lyctus brunneus beetles attack the sapwood of several host plants, Bain 1978 found that Lyctus brunneus bore sapwood of seasoned wood and partly seasoned hardwood timber, also Peters et al (2002) stated that the powder post beetles attack sapwood of certain hardwood and no attack softwoods. In this respect, Kvamma (1982) recorded that Lyctus brunneus beetle on Quercus spp., while Shi and Tan 1987 found that Lyctus brunneus is one of eight species of Lyctidae attack Chinese hardwood. Suzuki (1983) reared Lyctus brunneus beetle on buckwheat cake.

In Iran Niloufari 1985 and Modarres Awal 1997 found that Lyctus brunneus infest dry wood of Alnus, Carpinus (Betulaceae), Ulmus (Ulmaceae), Acer (Aceraceae), Fagus (Fagaceae), Populus 
(Salicaceae), and furniture and also construction timbers.

In Egypt, Lyctus brunneus was recorded by El-Zoheiry and Mohamed (1949) also, Nour (1963a) found that Lyctus brunneus is one of Lyctid beetles which recorded on some wood species as bamboo, oak, beech, sisso and acacia, the same author (1963b) remember that adult Lyctid beetles were attracted to light and found that the time of adult emergence varied according to the time of wood infestation. While, Alfieri (1976) recorded Lyctus brunneus from Cairo vicinity and found that this beetle emerged all year round from dry bamboo, Alibizzia lebbek Benth., dry timber and oak floors. Hamad and Aly 1985 stated that the Lyctus brunneus attracted to light trap of the Robinson type during months from September until November in 1974 and during months from March until August in 1975 at Quena governorate.

As well, some researchers, such as Helal (1986) and Batt (1989), surveyed Lyctus africanus Lesne from fig, mango, acacia, mulberry, sisso, poinciana, willow and sesbane trees as well as bamboo and cotton stalks, while Ali (2013) reared Lyctus africanus on some previous hosts, as well as, lebbek, casuarina, kaya, palm fronds, poplar and eucalyptus trees, also Shalaby (1958) reported Lyctus impressus Lom. from oak floors, whereas Haggag and Batt (2000) found that Lyctus impressus beetle infest citrus branches.

The length of emergence period of wood boring beetles from infested wood (in their different shape and uses) under suitable circumstances give the chance to replicate the infestation in same host or new suitable wood.

The aim of this work is to determine the emergence period, number of emerged Lyctus brunneus beetle during the occurrence periods and the effect of temperature, relative humidity and wood moisture content on population of beetles.

\section{MATERIALS AND METHODS}

Infested wood boards with Lyctus brunneus Steph. beetles (Coleoptera: Bostrichidae) were collected from wooden floors which have evident signs of infestation (small circular emergence holes or fine boring dust on external surface wood) at Giza governorate during late December 2015. These boards were made from bamboo Parquet wood (the measures of wood board were $22.5 \mathrm{~cm}$ $\times 12.5 \mathrm{~cm} \times 1.5 \mathrm{~cm}$ ). The boards were kept in plastic boxes $(27 \mathrm{~cm} \times 17 \mathrm{~cm} \times 14 \mathrm{~cm})$, each box contain 5 pieces of wood boards and covered with muslin cloth (replicated10 times). Closed observation was made to record the number of emerged beetles during different months of 2016 and 2017 under laboratory conditions of temperature and relative humidity.

The emergence periods of beetles during the storage period were studied, percentage of emergence and peaks of population were determined, monthly temperature and relative humidity averages were calculated. Also Monthly percentages of wood moisture content were determined by measurement apparatus of wood moisture content.

The effect of temperature, relative humidity and percentage of wood moisture content on number of emerged beetles during occurrence periods was studied by simple correlation and regression, according to SAS (2001).

\section{RESULTS AND DISCUSSION 1-Monthly numbers and percentage of emerged beetles under laboratory conditions: \\ Data on the emergence activity of Lyctus brunneus beetles estimated by}


monthly number and percentages of $L$. brunneus beetles emerged from infested floor boards storage for two years are illustrated in Tables (1 and 2).

The recoded data detected that the total cumulative number of emerged beetles was 492 during the storage period which its duration was 24 months, extending from early January 2016 to late December 2017.

During the first year of storage (2016), the monthly population for emerged beetles showed that the highest number of emerged beetles was 130 beetles (30.95\% from seasonal emergence) recorded in May 2016, at Temp. $28.3^{\circ} \mathrm{C}$ and $36.2 \% \mathrm{RH}$. The emergence of beetles stopped during August, September and October, and then it started again during November recorded 12 beetles $(2.86 \%$ emergence) at Temp. $21.4^{\circ} \mathrm{C} \& 57.6 \% \mathrm{RH}$. and December 201640 beetles $(9.53 \%$ emergence) at Temp. $18.9^{\circ} \mathrm{C}$ and $59.2 \%$ RH. The cumulative number of emerged beetles reached 420 beetles at the end of the first year of emergence, Table (1)

During the second year of storage (2017), the beetles emergence continued through January recorded 28 beetles (38.89\% from seasonal emergence) at $14.5^{\circ} \mathrm{C}$ and $53.9 \%$ RH.), and February recorded 6 beetles ( $8.33 \%$ emergence) at $17.2{ }^{\circ} \mathrm{C}$ and $49.1 \% \mathrm{RH}$., afterwards the emergence of beetles ceased during the period from March to June 2017, whereas the emergence continued through July recoded 20 beetles $(27.78 \%$ emergence) at Temp. $30.7^{\circ} \mathrm{C}$ and $43.9 \%$ RH., until October recorded one beetle $(1.39 \%$ emergence) at Temp. $26.2^{\circ} \mathrm{C}$ and $54.7 \%$ RH., Table (2).

Table (1): Monthly number and percentages of Lyctus brunneus beetles emerged from infested wood storage under laboratory conditions during 2016 year.

\begin{tabular}{|c|c|c|c|c|c|c|}
\hline \multirow{2}{*}{ Months } & \multicolumn{2}{|c|}{ No. of emerged beetles } & \multirow{2}{*}{$\begin{array}{c}\text { Emergence } \\
\%\end{array}$} & \multicolumn{2}{|c|}{ Lab. conditions } & \multirow{2}{*}{$\begin{array}{c}\text { Moisture } \\
\text { content of } \\
\text { wood \% }\end{array}$} \\
\hline & monthly & cumulative & & Temp. ${ }^{\circ} \mathbf{C}$ & RH.\% & \\
\hline Jan. & 0 & 0 & 0 & 15.3 & 55.6 & 10.2 \\
\hline Feb. & 14 & 14 & 3.33 & 16.9 & 52.5 & 9.6 \\
\hline Mar. & 42 & 56 & 10 & 19.1 & 47.8 & 8.7 \\
\hline April & 98 & 154 & 23.33 & 24.8 & 41.6 & 7.6 \\
\hline May & 130 & 284 & 30.95 & 28.3 & 36.2 & 6.7 \\
\hline Jun. & 57 & 341 & 13.57 & 29.7 & 39.4 & 7.4 \\
\hline Jul. & 27 & 368 & 6.43 & 27.9 & 43.6 & 7.9 \\
\hline Aug. & 0 & 368 & 0 & 31.8 & 48.8 & 8.8 \\
\hline Sep. & 0 & 368 & 0 & 28.8 & 50.4 & 9 \\
\hline Oct. & 0 & 368 & 0 & 25.9 & 49.6 & 9.1 \\
\hline Nov. & 12 & 380 & 2.86 & 21.4 & 57.6 & 10.4 \\
\hline Dec. & 40 & 420 & 9.53 & 18.9 & 59.2 & 11 \\
\hline Total & 420 & 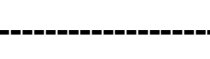 & $100 \%$ & --------- & 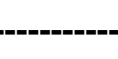 & -.----.-. \\
\hline
\end{tabular}


Table (2): Monthly number and percentages of Lyctus brunneus beetles emerged from infested wood storage under laboratory conditions during 2017 year.

\begin{tabular}{|c|c|c|c|c|c|c|}
\hline \multirow{2}{*}{ Months } & \multicolumn{2}{|c|}{ No. of emerged beetles } & \multirow{2}{*}{$\begin{array}{c}\text { Emergence } \\
\%\end{array}$} & \multicolumn{2}{|c|}{ Lab. conditions } & \multirow{2}{*}{$\begin{array}{c}\text { Moisture } \\
\text { content of } \\
\text { wood \% }\end{array}$} \\
\hline & monthly & cumulative & & Temp. $^{\circ} \mathrm{C}$ & RH. \% & \\
\hline Jan. & 28 & 448 & 38.89 & 14.5 & 53.9 & 10 \\
\hline Feb. & 6 & 454 & 8.33 & 17.2 & 49.1 & 9.2 \\
\hline Mar. & 0 & 454 & 0 & 24.2 & 42.6 & 7.9 \\
\hline April & 0 & 454 & 0 & 29.3 & 41.8 & 7.7 \\
\hline May & 0 & 454 & 0 & 27.8 & 36.8 & 7.1 \\
\hline Jun. & 0 & 454 & 0 & 29.1 & 38.6 & 7.4 \\
\hline Jul. & 20 & 474 & 27.78 & 30.7 & 43.9 & 8 \\
\hline Aug. & 13 & 487 & 18.05 & 32.3 & 45.9 & 8.3 \\
\hline Sep. & 4 & 491 & 5.56 & 29.9 & 48.9 & 8.9 \\
\hline Oct. & 1 & 492 & 1.39 & 26.2 & 54.7 & 9.7 \\
\hline Nov. & 0 & 492 & 0 & 20.8 & 56.9 & 10.3 \\
\hline Dec. & 0 & 492 & 0 & 19.2 & 58.2 & 10.8 \\
\hline Total & 72 & ----------------- & $100 \%$ & ---------. & & 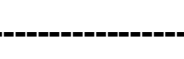 \\
\hline
\end{tabular}

The cumulative number of emerged beetles until the emergence end of the Second year recorded 492 beetles, while it was only 72 beetles during the 2 nd year.

\section{2- Occurrence periods, emergence percentage and population peaks of Lyctus brunneus beetles:}

Obtained data on the occurrence periods and percentages of beetles emergence with peaks of $L$. brunneus beetles population emerging from storage wooden boards are recorded in Table (3).

Three occurrence periods of beetles are clearly apparent:

The first occurrence period recorded 6 months, during the period from February 2016 to July 2016. The percentage of emergence was $74.80 \%$ from the total population of emerged beetles during two years of storage. The peak population of the first occurrence periods recorded during May 2016 when the percentage of emergence was $35.33 \%$ from population of first occurrence period.

The second occurrence period recorded 4months, during elapsed period from November 2016 until February 2017. The percentage of emergence during the second period was $17.48 \%$ from population of emerged beetles during the total storage periods (January 2016 to late 2017). The emergence peak of population during the 2nd occurrence showed $46.51 \%$ from beetles population of 2nd occurrence recorded during December 2016. 
Table (3): Occurrence periods, emergence percentages and population peaks of Lyctus brunneus beetles emerged from storage wood under laboratory conditions.

\begin{tabular}{|c|c|c|c|c|c|c|c|}
\hline \multirow{2}{*}{$\begin{array}{l}\text { occurrence } \\
\text { periods }\end{array}$} & \multicolumn{5}{|c|}{ Data of occurrence } & \multicolumn{2}{|c|}{$\begin{array}{l}\text { Peaks of } \\
\text { emergence }\end{array}$} \\
\hline & from & to & $\begin{array}{l}\text { Duration } \\
\text { in month }\end{array}$ & $\begin{array}{c}\text { No. of } \\
\text { emerged } \\
\text { beetles }\end{array}$ & $\begin{array}{c}\text { Emergence } \\
\%\end{array}$ & Month & $\begin{array}{c}\text { Emergence } \\
\%\end{array}$ \\
\hline 1st & $\begin{array}{l}\text { Feb. } \\
2016\end{array}$ & $\begin{array}{l}\text { Jul. } \\
2016\end{array}$ & 6 & 368 & $74.80 \%$ & $\begin{array}{l}\text { May } \\
2016\end{array}$ & $\begin{array}{l}(130 / 368) \\
=35.33 \%\end{array}$ \\
\hline 2nd & $\begin{array}{l}\text { Nov. } \\
2016\end{array}$ & $\begin{array}{l}\text { Feb. } \\
2017\end{array}$ & 4 & 86 & $17.48 \%$ & $\begin{array}{l}\text { Dec. } \\
2016\end{array}$ & $\begin{aligned} & (40 / 86) \\
= & 46.51 \%\end{aligned}$ \\
\hline $3 \underline{\text { rd }}$ & $\begin{array}{l}\text { Jul. } \\
2017\end{array}$ & $\begin{array}{l}\text { Oct. } \\
2017\end{array}$ & 4 & 38 & $7.72 \%$ & $\begin{array}{l}\text { Jul. } \\
2017\end{array}$ & $\begin{array}{c}(20 / 38) \\
=52.63 \%\end{array}$ \\
\hline \multicolumn{3}{|c|}{ Total } & 14 & 492 & $100 \%$ & \multicolumn{2}{|c|}{ 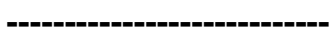 } \\
\hline
\end{tabular}

The third occurrence period also recorded 4 months of beetle's emergence, during the period from July 2017 until October 2017. The percentage of emergence through this period was $7.72 \%$ from total beetles population emerging during the storage period. The peak of emergence for the third occurrence observed during July 2017 when the percentage of population was $52.63 \%$ from the number of emerged beetles during the third occurrence.

3- Effect of temperature, relative humidity and moisture content of wood on population of beetles emerging during different occurrence periods from storage infested wood:

The effect of temperature, relative humidity and moisture content of wood on population of emerged beetles was studied by determination of simple correlation and simple regression values, Table (4) .

a- Effect of temperature:

The correlation between laboratory temperature and number of emerged beetles from storage wood showed differences in the significance of values through the three occurrence periods, the correlation was positive during the first occurrence period $(r=0.508 \& b$ $=4.262$ ) and highly positive during the third occurrence $(r=0.719 \& b=2.409)$, while the correlation was insignificant during the second occurrence $(r=-0.193$ $\& b=-1.029$ ), Table(4). Nour (1963b) found that the number of emerging Lyctus africanus beetles correlated positively with temperature.

b- Effect of relative humidity:

The correlation between the relative humidity and number of emerged beetles during the different occurrence periods showed highly negative significant correlation through the1st occurrence period $(r=-0.815 \& b=-6.153)$ and the 3rd occurrence period $(r=-0.919 \& b=$ 1.691), while the correlation was high significant and positive through the 2 nd occurrence period $(r=0.661 \& b=2.273)$, Table (4). 
Table (4): Simple correlation ( $r$ ) and simple regression (b) between factors affecting on population (Temp. ${ }^{\circ} \mathrm{C}, \mathrm{RH} \%$ and Moisture content of wood \%) and number of emerged beetles of Lyctus brunneus during occurrence periods.

\begin{tabular}{|c|c|c|c|c|c|c|}
\hline \multirow{3}{*}{$\begin{array}{l}\text { occurrence } \\
\text { periods }\end{array}$} & \multicolumn{6}{|c|}{ Factors affecting on population } \\
\hline & \multicolumn{2}{|c|}{ Temperature $^{\circ} \mathrm{C}$} & \multicolumn{2}{|c|}{ Relative humidity \% } & \multicolumn{2}{|c|}{$\begin{array}{l}\text { Moisture content of } \\
\text { wood } \%\end{array}$} \\
\hline & $\mathbf{r}$ & b & $\mathbf{r}$ & b & $\mathbf{r}$ & b \\
\hline 1st & 0.508 & 4.262 & -0.815 & -6.153 & -0.821 & -35.527 \\
\hline 2nd & -0.193 & -1.029 & 0.661 & 2.273 & 0.775 & 15.848 \\
\hline $3 \underline{\text { rd }}$ & 0.719 & 2.409 & -.0 .919 & -1.691 & -0.942 & -10.879 \\
\hline
\end{tabular}

Ali (2013) found that there is no correlation between the number of emerged Lyctus africanus beetles and mean conditions. The occurrence period was not correlated with total number of emerged beetles.

c- Effect of moisture content of wood:

During the different occurrence periods, the correlation between the percentages of wood moisture content and number of emerged beetles indicated highly negative significant correlation through the 1st occurrence period $(r=-$ $0.821 \& b=-35.527)$ and the $3 \underline{r d}$ occurrence period $(r=-0.942 \& b=-$ 10.879), while the correlation was high significant and positive through the 2 nd occurrence period $(r=0.775 \& b=$ 15.848), Table (4) .

Okil (1982) found that the infestation of Sinoxylon sudanicum Lesne correlate with a range of moisture content from 13.6 to $35.6 \%$ for Poinciana regia wood branches preserved under laboratory condition. Also, El-Sebay (1984) mentioned that the highest number of emerged beetles and lowest one were produced from infested wood bamboo with Dinoderus bifovealotus as an effect of corresponding percentage of moister content $39.4 \%$ and $9.4 \%$., respectively

The previously mentioned results indicated that the wooden structures and floor boards infested with lyctid beetles special in closed places are considered as renewal for source of infestation.

\section{REFERENCES}

Alfieri, A. (1976). The Coleoptera of Egypt. Memoires de la Societe Entomologique d'Egypte, 361pp.

Ali, H.R.K. (2013). Biological and ecological aspects of the powder post beetles Family Lyctidae and control of wood borers using wood preservatives. Ph.D. Thesis, Fac., Agric. Fayoum Univ., Egypt, 189pp.

Bain, J. (1978). Lyctus brunneus Steph. (Coleoptera:Lyctidae) a powder post beetle. Forest and Timber. Insects in New Zealand (33):7pp.

Batt, A.M. (1989). Biological, ecological and control studies on some wood borers in Egypt. Ph.D. Thesis, Fac. Agric., Minufiya Univ., Egypt, 238pp.

El-Sebay, Y. (1984). Biological, ecological and control studies of the wood borers, Bostrychopsis reichei Mars., and Dinoderus bifoveolatus Woll. (Bostrychidae) and Macrotoma palmata F. (Cermbycidae). Ph.D. 
Thesis, Fac. Agric. Al-Azhar, Univ., Cairo, 251 pp.

El-Zoheiry, M.S. and N. Mohamed (1949). List of Egyptian insects in the collection of entomological section. Entomological section, Ministry of Agriculture, Egypt, 87pp

Haggag, S.M. and A.M. Batt (2000). Biolgogical and ecological studies on the Lyctid beetle, Lyctus impressus Lom. (Coleoptera:Lyctidae) on citrus trees in Egypt. Egypt J. Agric. Res., 78((1): $79-89$.

Hamad, N. E. F. and M.Z.Y. Aly (1985). Seasonal fluctuations of certain species of nocturnal Coleoptera as indicated by a light trap at Qena Univ. Sci. Bull. 5: 287-304

Helal, H. (1986). Wood boring insect species and their host plants in Egypt. Agric Res. Rev., Egypt, 64(1):21-49.

Kvamme, T. (1982). New records of Norwegian Coleoptera I: species new to the fauna. Fauna. Norvegiaca. B 29(1): 34-35.

Modarres Awal, M. (1997). Bostrichidae; Lyctidae. In: List of agricultural pests and their natural enemies in Iran. Mashhad, Iran: Ferdowsi University Press pp. 129-130, 175.

Niloufari, P. (1985). Studies on the infestation behaviour of the powderpost beetle Lyctus brunneus (Steph.) and its physical control in the wood yards of the Caspian forests of Iran. International Research Group on Wood Preservation, IRG/WP 1271.

Nour, H. (1963a). Classification of wood boring beetles as known to exist in
Egypt., U.A.R. (Col.) Tech. Bull., Min. Agric., Dokki, Giza, Egypt, 35pp.

Nour, H. (1963b). Biological studies on Lyctus africanus Lesne (Lyctidae: Coleoptera). Bull Soc. Ent. Egypt, Xi, Vii: 51-57

Okil, A.M. (1982). Studies on Sinoxylon sudanicum Lesne (Col., Bostrichidae). M.Sc. Thesis, Fac. Agric., Al-Azhar Univ., Cairo, 77pp.

Peters, B.C., J.W. Crffield and R.H.E Idridge (2002). Lyctine (Coleoptera: Bostrichidae) pests of timber in Australia: A literature, review and susceptibility testing protocol. Australian forestry, Res.Inst.65 (2): 107-119.

SAS institute (2001). Version 8.02.SAS Institute, Cary, N C.

Shalaby, F. (1958). Alphabetical list of Egyptian insects in the collection of Ministry of Agriculture. Min., Agric. Teach. Bull. No. 284

Shi, Z.H. and S.O. Tan (1987). The susceptibility of Chinese hard-wood to powder post beetles attack and methods of control. Scientia -Silvae Sinicae 1987:23.

Suzuki, K. (1983). Rearing of Lyctus brunneus Steph. on Buckwheat cake (Fagoporim sagittatim Gilb) and tentative method for determination of the efficacy of preservative compounds. Appli. and Zool., 18 (3): 308-314.

Thakur, M.L. (1999). Insect pest status of poplars in India. Indian-For.125(9): 872 $-886$. 
نشاط خروج الخنافس الساحقة Lyctus brunneus (Stephens) من الخثب المصاب المخزن لفترة محددة

\author{
محمد عبد الغنى بط ، حسن محمد أحمد
}

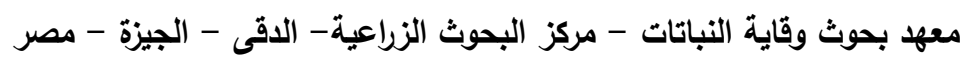

الملخص العربى

أجرى هذا البحث لمعرفة نثاط خروج ختافس Lyctus brunneus من أخثاب الباركية المصابة بهذه الحشرة

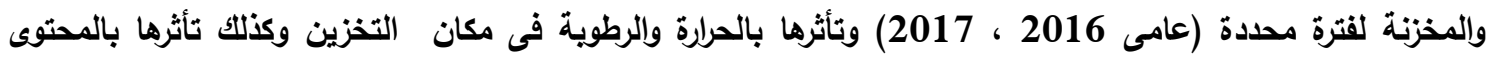
الرطويى للخثب خلال تلك الفترة.

و تثثير نتائج البحث الى أن خنافس Lyctus brunneus الخارجة من الخثب المصاب المخزن لفترة محددة فى

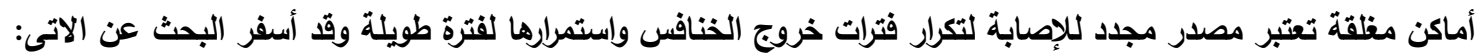

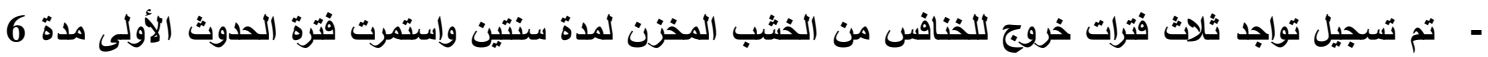

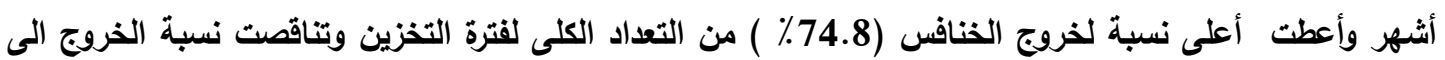

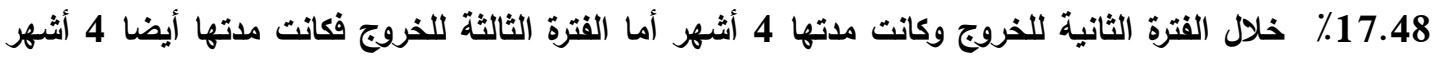
ولكنها أظهرت أقل نسبة لخروج الخنافس (7.72 (7.72 ).

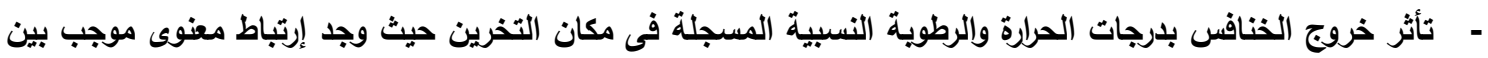

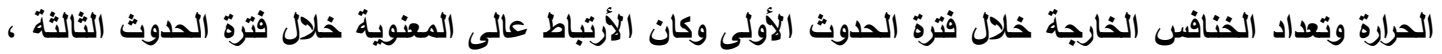

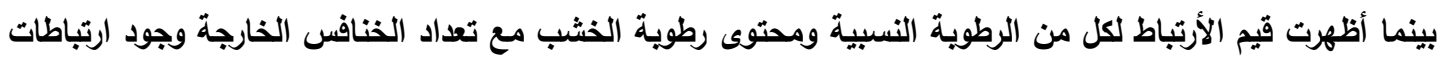

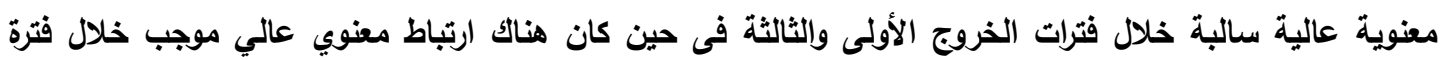

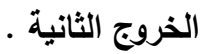

